\title{
Pengembangan Lembaran Kerja Matematika SMP Berbasis Pendekatan Metakognisi untuk Meningkatkan Higher Order Thinking Skill Peserta Didik
}

\author{
Nadia Alkhaira ${ }^{1}$, Yerizon ${ }^{2 *}$ \\ ${ }^{1,2}$ Universitas Negeri Padang, Padang, Sumatera Barat 25131, Indonesia
}

Pengiriman: 10 Agustus 2019; Diterima: 24 Oktober 2019; Publikasi: 31 Oktober 2019

DOI: https://doi.org/10.31629/jg.v4i2.1418

\begin{abstract}
Abstrak
Tujuan dari penelitian ini adalah menghasilkan lembaran kerja Matematika SMP berbasis pendekatan metakonigsi yang valid, praktis, dan efektif untuk meningkatkan HOTS peserta didik. Penelitian ini merupakan penelitian pengembangan dengan menggunakan model Plomp.dengan tahapan preliminary research, prototyping stage, dan assessment stage. Instrumen yang digunakan adalah angket dan tes. Teknik analisis data dengan menggunakan pesrsentase. Hasil dari penelitian ini adalah lembaran kerja berbasis metakognisi a) valid dari aspek isi, konstruk, bahasa, dan kegrafikaan, b) praktis dari aspek penggunaan, waktu dan keterbacaan, dan c) efektif dari aspek untuk meningkatkan kemampuan HOTS peserta didik.
\end{abstract}

Kata kunci: metakognisi; higher order thinking skill; lembaran kerja

\begin{abstract}
The purpose of this study is to produce a valid, practical and effective Junior High School Mathematics worksheet based on metacognition approach to improve students' HOTS. This research is a development research using Plomp model with three stages, namely the preliminary investigation, prototyping stage, and assessment phase. The instruments used were questionnaires and tests. The results of this study is metacognition-based worksheet which is a) valid from the aspect of content, construct, language, and graphic, b) practical from the aspect of usage, time and readability, and c) effective from the aspect of improving the HOTS ability of students.
\end{abstract}

Keywords: metacognition; higher order thinking skill; worksheet

\section{Pendahuluan}

Sumber daya manusia yang cerdas, cekatan, berpikir kritis dan rasional adalah sumber daya manusia yang dibutuhkan untuk menghadapi tantangan abad 21. Sumber daya manusia yang berkualitas berbanding lurus dengan kualitas pendidikan, dimana agar memperoleh sumber daya manusia yang baik dibutuhkan pendidikan yang berkualitas.
Sebagai tantangan menghadapi abad 21 dan menghasilkan sumber daya manusia yang cerdas, kritis, kreatif dan inovatif, Kementerian Pendidikan dan Kebudayaan Indonesia mencanangkan adanya keharusan pembelajaran yang berorientasi pada peningkatan kemampuan berpikir tingkat tinggi. Hal ini terlihat pada pengimplementasian Kurikulum 2013 edisi revisi 2017 pada pembelajaran matematika

*Penulis Korespondensi 


\section{JURNAL GANTANG. Oktober 2019; IV(2): 143 - 153 \\ p-ISSN. 2503-0671 \\ e-ISSN. 2548-5547}

peserta didik tidak hanya dibekali dengam kemampuan menggunakan perhitungan rumus dalam pengerjaan soal tes saja namun lebih dari itu peserta didik diharapkan mampu melibatkan kemampuan bernalar dan analitisnya dalam pemecahan masalah sehari-hari (Prasetyani, Hartono, \& Susanti, 2016). Oleh karena itu sebagai tolak ukur peningkatan kemampuan berpikir tingkat tinggi peserta didik dan peningkatan standarisasi pendidikan pada ujian nasional dimunculkan soal-soal level Higher Order Thinking Skill (HOTS).

Kemampuan berpikir tingkat tinggi atau dikenal dengan istilah HOTS adalah keterampilan yang lebih dari sekedar mengingat, memahami dan mengaplikasikan HOTS menuntut seseorang untuk menerapkan informasi baru atau pengetahuan yang telah dimilikinya dan memanipulasi informasi untuk menjangkau kemungkinan jawaban dalam situasi yang baru (Thompson, 2008) Dengan demikian, HOTS merupakan suatu keterampilan berpikir yang tidak hanya membutuhkan kemampuan mengingat, tetapi juga kemampuan lain yang lebih tinggi meliputi kemampuan menganalisis, mengevaluasi, dan mencipta (Kamarudin, Yusoff, Yamat, \& Ghani, 2016).

Beberapa penelitian terdahulu telah dilakukan terkait HOTS seperti yang dilakukan Rooney (2009) yaitu dengan menerapkan pembelajaran berbasis inkuiri. Demikian juga yang dilakukan Widodo \& Kadarwati (2013) yaitu penerapan pembelajaran berbasis masalah untuk meningkatkan HOTS siswa. Namun mereka belum membuat lembaran kerja yang khusus untuk memfasilitasi HOTS.

Pengimplementasi soal-soal level HOTS pada Ujian Nasional (UN) ini tidak diiringi kesiapan peserta didik dalam menyelesaikan soal-soal level HOTS. Pada UN matematika 2017 berdasarkan data Kementerian Pendidikan dan Kebudayaan, soal level HOTS dimunculkan $10 \%$ namun dari hasil UN diperoleh $40 \%$ peserta didik kesulitan dalam menjawab soal level HOTS. Oleh sebab itu, Untuk menelusuri bagaimana kesiapan peserta didik dalam menjawab soal level HOTS peneliti melakukan pengujian soal level HOTS kepada 20 orang peserta didik (Lestari, Kristiana, \& Kurniati, 2016).

Dari jawaban-jawaban yang diberikan peserta didik kelemahan peserta didik dalam menjawab soal level HOTS disebabkan oleh peserta didik masih lemah dalam mengidentifikasi masalah yang diberikan, sehingga peserta didik tidak mampu merencanakan strategi yang tepat untuk menyelesaikan soal yang diberikan. Disamping itu juga terlihat peserta didik tidak mencoba menganalogikan masalah kedalam bentuk yang lebih sederhana dan mudah dipahami.Sebagian besar peserta didik merasa yakin dengan jawabannya, tetapi mereka lupa mengoreksi kembali kebenaran setiap langkah yang dikerjakan dan tidak mampu memberikan argumentasi yang sahih dari setiap langkah yang dikerjakan. Hal ini berarti peserta didik belum memiliki kemampuan berpikir kritis.

Schafersman menyatakan seseorang yang memiliki kemampuan berpikir kritis dapat mengajukan pertanyaan-pertanyaan yang sesuai, mengumpulkan informasi yang relevan, secara efisien dan kreatif mereka menyusun dan berbuat melalui informasi yang dikumpulkannya itu, bernalar secara logika berdasar informasi, dan datang dengan kesimpulan yang reliabel dan dapat dipercaya tentang lingkungan yang memungkinkannya tinggal dan berhasil di dalamnya (Ali \& Zulkifli, 2016). Namun, dalam mengerjakan soal level HOTS yang diberikan mereka belum mampu menyakinkan beberapa alternatif solusi yang bernilai benar dari sebuah persoalan dan mengambil keputusan mengenai pemecahan masalah yang paling tepat dan efisien (Abdullah \& Richardo, 2017).

Pada jawaban peserta didik juga tampak peserta didik tidak memiliki keyakinan diri untuk mampu memecahkan permasalahan yang diberikan. Berdasarkan uraian di atas dapat ditarik kesimpulan bahwa terdapat beberapa keterampilan yang belum dimiliki oleh peserta didik, keterampilan tersebut diantaranya: 
pemecahan masalah, pengambilan keputusan, berpikir kritis, dan berpikir kreatif. Keempat kemampuan ini dinamakan dengan HOTS.

Mengatasi permasalahan di atas salah satu aspek yang perlu dikembangkan adalah pengelolaan pembelajaran matematika yang efektif dan efesien dalam membelajarkan peserta didik, baik dalam berpikir secara logis, sikap dan keterampilan (Astuti, Purwoko, \& Indaryanti, 2017). Pembelajaran yang efektif adalah pembelajaran yang mempunyai persiapan dan pelaksanaan yang sitematis serta dituangkan dalam bentuk perangkat pembelajaran. Salah satu perangkat yang dapat digunakan adalah Lembar Kerja Peserta Didik (LKPD). Perangkat pembelajaran yang efektif disini adalah perangkat pembelajaran dengan model pembelajaran yang dirancang dapat melatih peserta didik terbiasa dengan soal level HOTS. Berdasarkan karakteristik HOTS salah satu pendekatan yang dapat dilakukan untuk meningkatkan kemampuan tersebut adalah menyadarkan kemampuan kognisi peserta didik, proses penyadaran kemampuan kognisi ini merupakan upaya secara metakognisi.

Metakognisi merupakan istilah yang diperkenalkan Flavell tahun 1976. Flavell menyatakan bahwa metakognisi merupakan kesadaran seseorang tentang proses kognitifnya dan kemandiriannya untuk mencapai tujuan tertentu. Dengan kata lain metakognisi juga sebagai bentuk kemampuan seseorang melihat pada diri sendiri sehingga apa yang dilakukannya dapat terkontrol secara optimal (Services, 2009).

Ada tiga perilaku metakognisi dalam pembelajaran matematika yaitu: keyakinan dan intuisi, pengetahuan mengenai proses berpikir dan pengaturan diri (Lai, 2011). Sehingga dengan ketiga perilaku ini peserta didik akan memiliki kemampuan untuk pemecahan masalah, pengambilan keputusan, berpikir kritis, dan berpikir kreatif atau disebut juga dengan kemampuan berpikir tingkat tinggi (PapleontiouLouca, 2003).

Hal ini karena dalam setiap langkah yang mereka kerjakan senantiasa muncul pertanyaan: "Apa yang saya kerjakan?"; "Mengapa saya mengerjakan ini?"; "Hal apa yang dapat membantu saya dalam menyelesaikan masalah ini?"; "Apakah strategi yang saya gunakan sudah tepat?"; "Apakah saya dapat mengerjakan dengan cara yang berbeda?". Kemampuan peserta didik bertanya pada diri sendiri dan menjawab pertanyaan-pertanyaan tersebut menunjukan bahwa peserta didik memiliki perilaku-perilaku metakognisi dalam berpikir tingkat tinggi (Lai, 2011).

Pembelajaran dalam upaya menumbuhkan perilaku-perilaku metakognisi dan pengontrolan terhadap proses berpikir dalam membangun pengetahuan yang utuh merupakan pembelajaran dengan pendekatan metakognisi. Serta dengan pembelajaran dengan pendekatan metakognisi peserta didik bisa menyadari pentingnya penguasaan sebuah kemampuan matematika, melatih kemandirian untuk belajar, dan memungkinkan siswa untuk menyadari kekurangan dan kelebihannya, sehingga dapat melakukan kontrol terhadap pengetahuannya (Heong et al., 2011).

Berdasarkan permasalahan yang telah dikemukakan di atas maka penulis mengembangkan lembaran kerja berbasis pendekatan metakognisi untuk meningkatkan HOTS. Tujuan penelitian ini adalah menghasilkan LKPD berbasis pendekatan metakognisi yang valid, pratikis dan efektif.

\section{Metode Penelitian}

Jenis Penelitian ini merupakan penelitian pengembangan (research development), yang menghasilkan suatu produk dalam pembelajaran yaitu LKPD berbasis pendekatan metakognisi untuk meningkatkan HOTS pada peserta didik kelas VIII SMP. Model pengembangan yang digunakan dalam penelitian ini adalah model pengembangan yang diadaptasi dari Model Plomp (Akker et al., 2013). Model pengembangan ini terdiri dari 3 tahap, yaitu fase investigasi awal (preliminary research), fase pengembangan atau pembuatan prototype (development or prototyping phase), dan fase penilaian (assessment phase) (Yerizon, Putra, \& Subhan, 2018).

a) Fase investigasi awal 


\section{JURNAL GANTANG. Oktober 2019; IV(2): 143 - 153 \\ p-ISSN. 2503-0671 \\ e-ISSN. 2548-5547}

Fase ivestigasi awal dilaksanakan dengan tujuan untuk mengetahui bentuk dan karakteristik LKPD yang akan dikembangkan. Fase ini dilaksanakan dengan beberapa kegiatan antara lain analisis kebutuhan, analisis kurikulum, analisis konsep dan analisis peserta didik.

b) Fase pengembangan prototype

Pada tahap ini dirancang LKPD berbasis pendekatan metakognisi untuk meningkatkan HOTS pada peserta didik SMP kelas VIII. Selanjutnya untuk memastikan LKPD yang dikembangkan valid, praktis dan efektif, dilaksanakan evaluasi formatif. Valid dari aspek isi, penyajian, kebahasaan, dan kegrafikaan. Praktis dari segi keterlaksanaan, waktu, kemudahan dalam pengunaan. Efektif dari segi dampak potensialnya terhadap kemampuan HOTS peserta didik (Nasution, Yerizon, \& Gusmiyanti, 2018). Langkah-langkah evaluasi formatif tersebut digambarkan seperti pada Gambar 1.

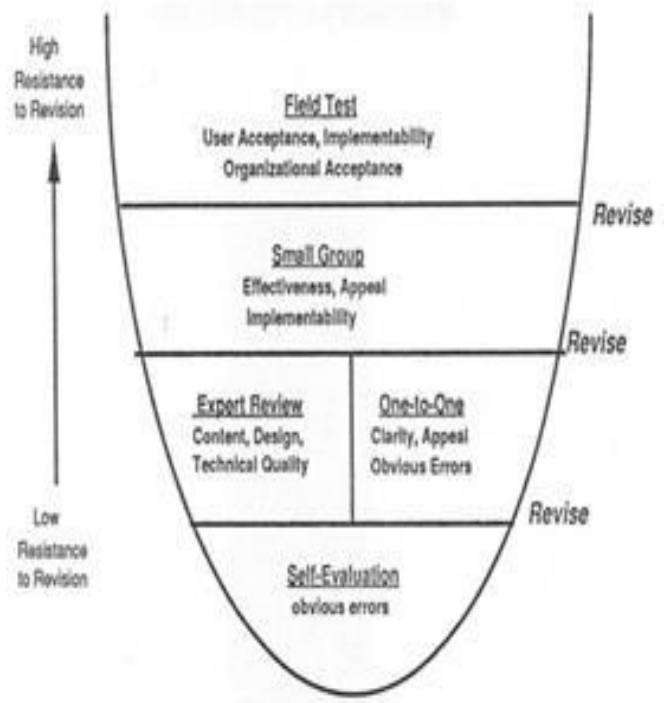

Sumber: (Akker et al., 2013)

Gambar 1. Lapisan-lapisan evaluasi formatif

c) Fase Penilaian

Penilaian dilaksanakan dengan melihat proses dan hasil belajar peserta didik kelas VIII SMP yang belajar dengan menggunakan LKPD tersebut. Aspek efektivitas yang diamati adalah kemampuan berpikir tingkat tinggi peserta didik. Kemampuan berpikir tingkat tinggi diukur melalui tes essay.

\section{Hasil dan Pembahasan}

1. Hasil tahap investigasi awal

Pada tahap ini dilakukan telaah terhadap kurikulum 2013 revisi 2017 yang digunakan untuk mata pelajaran matematika kelas VIII semester II. Analisis kurikulum dilakukan pada analisis kompetensi inti (KI) dan kompetensi dasar (KD) untuk materi kelas VIII semester II. Hasil analisis KI dan KD dipakai untuk merumuskan indikator pencapaian kompetensi.

Hasil analisis konsep juga untuk menggambarkan peta konsep dari setiap materi matematika semester II kelas VIII. Materi pada semester II kelas VIII diantaranya adalah Pythagoras, Lingkaran, Bangun Ruang Sisi Datar, Statistika dan Peluang.

Hasil analisis karakteristik peserta didik diperoleh bahwa peserta didik belum mempunyai kemampuan menyelesaikan soal HOTS. Berdasarkan hasil pengamatan terhadap pembelajaran matematika yang dilakukan, Hanya aspek kemampuan metakognisi sebagai syarat penguasaan kemampuan berpikir tingkat tinggi yang belum optimal dikembangkan dalam pembelajaran dikelas, serta diketahui peseta didik menyukai pembelajaran dengan LKPD yang bewarna dan menarik.

2. Tahap pengembangan prototype

Penerapan pendekaatan metakognisi pada LKPD yang digunakan sesuai dengan pendapat NCREL megemukakan tiga elemen dasar dari metakognisi secara khusus dalam pembelajaran, yakni: Perencanaan (Planning), Memantau (Monitoring), dan Evaluasi (Evaluation).

Pada perencanaan (Planning) pembelajaran dimulai dengan memberikan suatu permasalahan yang berkaitan dengan materi yang hendak di pelajari, kemudian peserta didik dituntun membuat perencanaan terhadap apa yang akan dipelajari. Peserta didik diberikan pertanyaan metakognisi untuk merencanakan atau mengembangkaan tindakan. Selain itu, pengajuan masalah pada tahap ini berfungsi untuk menyediakan kondisi interaksi belajar yang dapat mengembangkan dan membantu peserta didik dalam mengeksplorasi pengetahuannya.

Contoh penyajiannya dalam LKPD 
dapat dilihat pada Gambar 2.

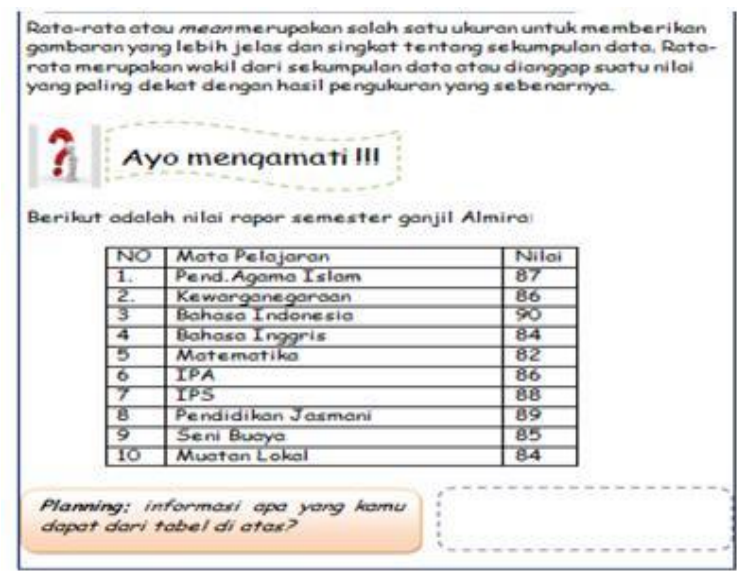

Gambar 2. Cuplikan perencanaan (Planning)

Peserta didik diminta untuk mengeksplorasi pengetahuannya tentang aspek yang berhubungan dengan rata-rata. Mereka diharapkan mempunyai rasa ingin tahu terhadap permasalahan yang diberikan.

Setelah mengumpulkan data atau menjawab pertanyaan pada LKPD peserta didik dituntun kembali dengan pertanyaan metakognisi yang bertujuan untuk mengatur/memonitor rencana dan tindakan yang telah mereka lakukan atau monitoring. Contohnya kegiatan memantau (monitoring) dapat dilihat pada Gambar 3.

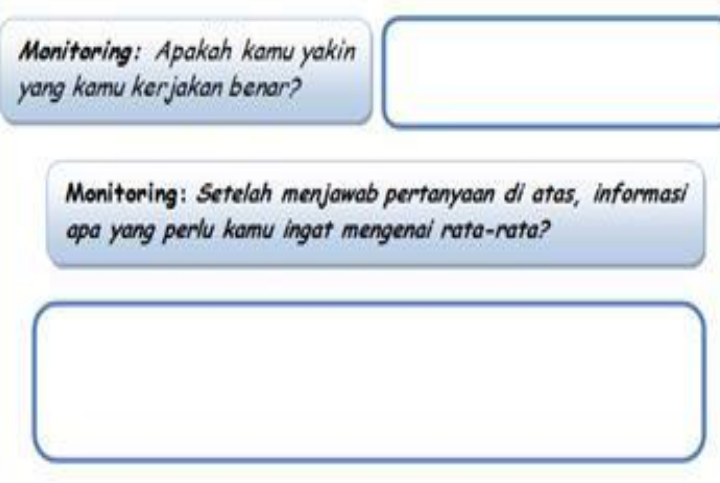

Gambar 3. Cuplikan pertanyaan monitoring

Berdasarkan pada contoh cuplikan pertanyaan monitoring LKPD pada Gambar 3 di atas terlihat terdapat dua pertanyaan monitoring yaitu (1) Apakah kamu yakin yang kamu kerjakan benar? (2) Setelah menjawab pertanyaan diatas, informasi apa yang perlu kamu ingat mengenai rata-rata? Pertanyaan pertama merupakan pertanyan yang bertujuan memonitor tindakan sebagai bagian dari refleksi diri. Pertanyaan kedua merupakan pertanyaan yang bertujuan sebagai pemantauan terhadap apa yang telah peserta didik kerjakan.

Kegiatan berikutnya adalah melakukan evaluasi. Peserta didik dituntun kembali dengan pertanyaan metakognisi yang bertujuan untuk mengevaluasi rencana dan tindakan yang telah mereka lakukan seperti pada Gambar 4.

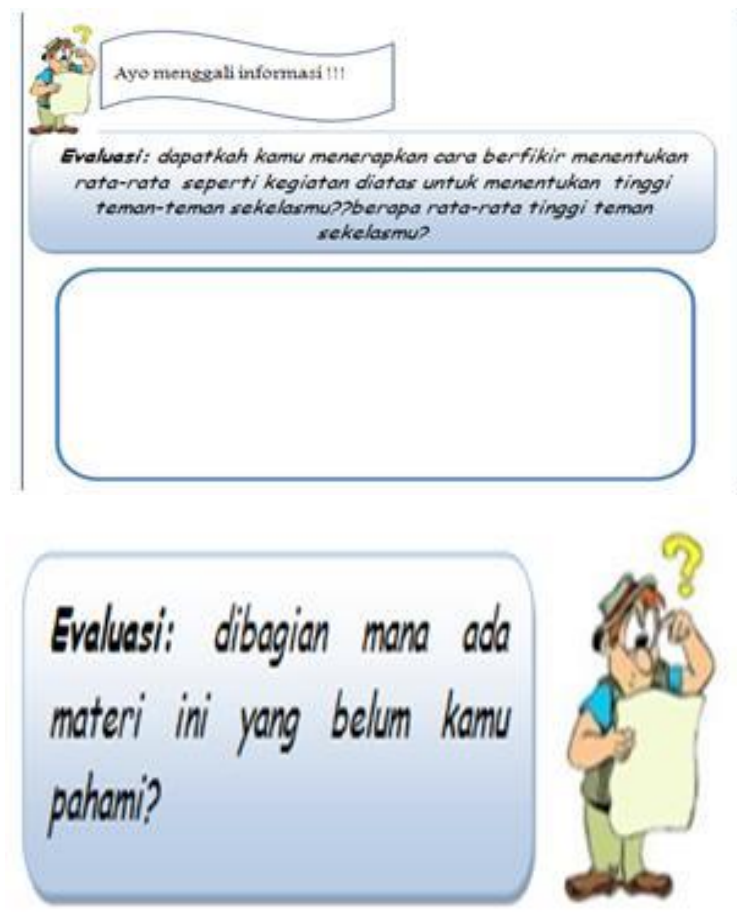

Gambar 4. Cuplikan pertanyaan evaluasi

Serangkaian pertanyaan-pertanyaan metakognisi ini bertujuan untuk memantau dan melatih kemampuan berpikir kritis peserta didik serta pertanyaan metakognisi untuk evaluasi bertujuan untuk melatih siswa berikir kreatif. Dengan demikian pengajuan pertanyaan metakognisi secara umum dapat dikatakan merupakan bagian melatih peserta didik dalam mengembangkan kemampuan berpikir tingkat tinggi.

Pada aspek penyajian terlihat cover dirancang sedemikian rupa untuk mencerminkan isi yang terkandung di dalam LKPD. Untuk meningkatkan minat belajar siswa LKPD disajikan dengan jenis tulisan Kristen ITC ukuran 16. Sedangkan untuk daftarnya yang digunakan jenis tulisan Comic sans MS 12. Selain itu, dalam penyajian LKPD bewarna sesuai dengan warna yang disukai peserta didik.

Dari aspek bahasa dan keterbacaan 


\section{JURNAL GANTANG. Oktober 2019; IV(2): 143 - 153 \\ p-ISSN. 2503-0671 \\ e-ISSN. 2548-5547}

terlihat bahwa penggunaan bahasa pada LKPD yang dikembangkan cukup jelas dan mudah dipahami. Bentuk dan ukuran huruf pada LKPD sesuai dengan keterbacaan peserta didik. Jenis tulisan yang digunakan pada cover adalah jenis huruf Tempus Sans ITC, Stencil, dan Rockwell dengan ukuran 48. Sedangkan pada isi LKPD ditulis dengan jenis huruf comic sans $M S$, dengan ukuran 12. Pemilihan jenis tulisan dan ukuran tulisan tersebut untuk memudahkan peserta didik membaca.

Setelah LKPD dikembangkan maka dilakukan evaluasi sendiri (Self Evaluation) yang bertujuan untuk melihat mengecek komponenkomponen dalam LKPD serta melihat kesalahan yang kasat mata, seperti kesalahan penulisan. Kesalahan banyak terjadi pada pengetikan kata dan tanda baca. Misalnya pada LKPD, kesalahan terjadi pada kata "menemukan", ditulis pada LKPD kata "mmenemukan" dan pada kata mentukan ditulis "mennentukan". Penulisan pada kata depan misalnya "di samping " ditulis " disamping". Kesalahan pada tanda baca misalnya, setelah kalimat diberi titik dengan jarak 1 spasi. Selain itu, kesalahan juga terlihat pada penulisan kalimat. Setelah dibaca berkalikali, masih ada beberapa kalimat yang sulit dipahami.

Selanjutnya expert review (tinjauan ahli) untuk memvalidasi LKPD yang terdiri dari aspek isi, materi, penyajian, kegrafikan dan bahasa. Saran-saran validator untuk LKPD dijadikan bahan untuk memperbaiki LKPD. Setelah dilakukan revisi, selanjutnya validator memberikan nilai terhadap LKPD matematika berbasis pendekatan metakognisi. Beberapa saran validator diantaranya ganti kolom jawaban peserta didik dengan garis penuh, sediakan juga kolom untuk menjawab pertanyaan metakognisi pada LKPD, ganti jenis font, serta Perbaiki EBI (Ejaan Bahasa Indonesia).

Hasil validasi menunjukkan bahwa untuk aspek komponen LKPD telah terpenuhi dengan sangat baik. Dapat dikatakan bahwa kegiatan pendahuluan, kriteria kevalidan LKPD yang dikembangkan adalah dalam segi isi dan konstruk. Setelah melakukan validasi maka diperoleh hasil validasi LKPD. Untuk aspek isi kevalidan LKPD memiliki rata-rata 3,38 yang tergolong sangat valid dan isi yang terkandung di dalam LKPD sangat jelas. Dapat disimpulkan bahwa LKPD yang digunakan telah memenuhi prinsip kedalaman dan ketepatan materi. LKPD telah memuat materi yang telah sesuai dengan $\mathrm{KI}$, KD dan indikator dengan jelas, langkahlangkah dalam LKPD telah menuntun peserta didik untuk menemukan konsep dan prinsip matematika, dan sudah terdapat soal dalam berbagai situasi. Penyusunan materi sangat tergantung pada KD yang akan dicapai.

Materi dalam LKPD dapat berupa informasi pendukung, yaitu gambaran umum atau ruang lingkup substansi yang akan dipelajari (Widodo dan Kadarwati, 2013). Ratarata kevalidan yang diperoleh untuk aspek bahasa adalah 3,3 yang dikategorikan sangat valid. Bahasa yang digunakan di dalam LKPD telah sesuai dengan EBI, pernyataan dan pertanyaan dalam LKPD sudah disusun dengan kalimat yang jelas, mudah dipahami, peserta didik, dan tidak memberi makna ambigu. Aspek penyajian yang terdapat dalam LKPD sudah tergolong sangat valid dengan nilai rata-rata yang diperoleh 3,64. Tampilan dalam LKPD sudah jelas dan menarik, bentuk dan ukuran huruf pada LKPD telah sesuai dengan keterbacaan peserta didik. Rata-rata kevalidan LKPD adalah 3,46 dengan kategori sangat valid. Berdasarkan hasil dari validasi LKPD matematika berbasis penemuan pendekatan metakognisi dikatakan valid, maka LKPD sudah memenuhi aspek yang diinginkan

Evaluasi One to One pertama dilakukan dengan meminta guru mata pelajaran matematika untuk memberi penilaian kritik dan saran mengenai LKPD yang akan digunakan untuk pembelajaran bagi peserta didik. Hasil One to One dengan guru matematika menjadi 12 jam pelajaran dengan 4 kali pertemuan untuk materi statistik dan 7 jam pelajaran dengan 2 kali pertemuan untuk materi peluang.

Evaluasi kedua dilakukan pada tiga orang peserta didik kelas VIII (3) SMP Negeri 2 Batusangkar dengan kemampuan belajar yang berbeda yaitu tinggi, sedang, dan rendah. Terdapat perbaikan kesalahan ketik dan kalimat yang kurang jelas. Semua kekurangan sudah diperbaiki. 
Evaluasi kelompok kecil diikuti oleh 6 orang peserta didik. Pada pelaksanaan uji lapangan pembelajaran dilakukan sesuai dengan LKPD yang telah dirancang. Dalam setiap pertemuan dilihat bagaimana peningkatan kemampuan peserta didik dalam menyelesaikan soal level HOTS. Peserta didik diminta untuk menyelesaiakan soal-soal pada latihan. Pada kegiatan ini peserta didik diminta untuk menuliskan kembali 11 data tinggi badan yang telah mereka dapatkan pada LKPD 1. Peserta didik diberikan pertanyaan yang menstimulus peserta didik untuk melakukan perencanaan mengenai median "Berdasarkan defenisi, cara apa yang kamu gunakan menetukan median data tersebut?" Peserta didik masih bingung. Untuk memfokuskan peserta didik diajukan pertanyaanpertanyaan yang kemudian dapat mengarahkan peserta didik dalam menentukan median dan modus suatu data. Selain itu peserta didik juga menjawab pertanyaan-pertanyaan pada LKPD yang dapat melatih kemampuan berpikir tingkat tinggi dan kemudian diikuti pertanyaan metakognisi yang menstimulus peserta didik untuk mengoreksi jawaban-jawaban dari pertanyaan yang telah mereka jawab "Apakah kamu yakin yang kamu kerjakan benar?" serta mengevaluasi sendiri pemahaman mereka mengenai menentukan median dan modus suatu data "Di bagian mana pada materi ini yang belum kamu pahami?"

Setelah menjawab pertanyaanpertanyaan pada LKPD, peserta didik dan guru membuat kesimpulan mengenai cara menentukan median dan modus suatu data. Kemudian peserta didik diminta untuk menyelesaikan soal-soal pada LKPD. Pada awalnya terlihat peserta didik agak kesulitan dalam menyelesaikan soal karena ada beberapa peserta didik yang bertanya mengenai maksud dari soal yang disajikan. Sama seperti pertemuan sebelumnya guru juga memberikan pertanyaan pancingan untuk menumbuhkan kesadaran peserta didik dalam menyusun rencana atau strategi dalam menyelesaikan soal tersebut seperti: "Coba pahami baik-baik, apa saja yang diketahui dalam soal tersebut!" Setelah diberikan pertanyaan pancingan peserta didik menyebut apa yang diketahui daam soal kemudian menuliskanya. Setelah itu guru kembali memberikan pertanyaan "Untuk memudahkan menjawab, dari yang diketahui pada soal apa yang dapat digunakan terlebih dahulu untuk menjawab soal?" Secara serempak peserta didik menjawab median.

Kemudian "Apa yang kamu lakukan untuk menentukan bilangan lainnya?" tidak ada respon dari peserta didik guru kembali mengarahkan "Baca kembali soalmu, imformasi apa yang dapat kamu gunakan untuk menetukan bilangan lainnya?" ada peserta didik yang menjawab rata-rata dan ada yang menjawab modus. Guru mengajukan pertanyaan kembali "Apakah kamu yakin caramu benar?" peserta didik mengulangi kembali membaca soal dan berdiskusi menyelesaikan soal.

Selanjutnya guru meminta peserta didik untuk menuliskan jawaban kedepan kelas, untuk proses evaluasi guru memberikan kembali stimulus "Dapatkah kamu menemukan kombinasi angka yang berbeda?" Terlihat peserta didik mengulangi kembali kegiatan yang mereka lakukan untuk menjawab soal. Kegitan ini dilakukan pada setiap petemuan pada small group evaluation.

Pada pelaksanaan uji lapangan pembelajaran dilakukan sesuai dengan LKPD yang telah dirancang. Dalam setiap pertemuan dilihat bagaimana peningkatan kemampuan peserta didik dalam menyelesaikan soal level HOTS. Peserta didik diminta untuk menyelesaiakan soal-soal pada latihan. Selanjutnya, peserta didik juga menjawab pertanyaan-pertanyaan pada LKPD yang dapat melatih kemampuan berpikir tingkat tinggi dan kemudian diikuti pertanyaan metakognisi yang menstimulus peserta didik untuk mengoreksi jawaban-jawaban dari pertanyaan yang telah mereka jawab serta mengevaluasi sendiri pemahaman mereka mengenai mennetukan ratarata suatu data.

Setelah menjawab pertanyaanpertanyaan pada LKPD peserta didik dan guru membuat kesimpulan mengenai cara menentukan rata-rata suatu data. Dalam setiap pembelajaran guru membimbing pesera didik dengan memberikan beberapa pertanyaan pancingan untuk menumbuhkan kesadaran siswa dalam menyusun rencana atau strategi dalam menyelesaikan soal tersebut seperti: "Coba 


\section{JURNAL GANTANG. Oktober 2019; IV(2): 143 - 153 \\ p-ISSN. 2503-0671 \\ e-ISSN. 2548-5547}

pahami baik-baik, apa saja yang diketahui dalam soal tersebut!" Setelah diberikan pertanyaan pancingan peserta didik menyebut apa yang diketahui daam soal kemudian menuliskanya. Setelah itu guru kembali memberika pertanyaan "Apa yang ditanya pada soal, dan untuk menjawabnya konsep apa yang bisa digunakan untuk menjawab pertanyaan tersebut!" Pemberian stimulus berupa pertanyaan ini dilakukan secara berulang pada setiap pertemuan dalam uji field test.

\section{Assesment Phase (Fase Penilaian)}

Uji praktikalitas dilakukan untuk melihat tingkat kepraktisan perangkat pembelajaran matematika saat digunakan dalam proses pembelajaran. Kegiatan ini dilakukan untuk mengetahui sejauh mana manfaat, kemudahan penggunaan, dan efisiensi waktu penggunaan perangkat pembelajaran matematika oleh guru dan peserta didik.

Hasil angket praktikalitas respon guru menunjukkan daya tarik, penggunaan, dan kemudahan penggunaan perangkat pembelajaran Data rata-rata item angket untuk tiap indikator disajikan pada Tabel 1.

Tabel 1. Hasil analisis kepraktisan angket guru

\begin{tabular}{llll}
\hline No & Indikator & Rata-rata & Kriteria \\
\hline 1 & Daya tarik & 93,75 & $\begin{array}{l}\text { Sangat } \\
\text { praktis }\end{array}$ \\
\hline 2 & Pengunaan LKPD & 75 & Praktis \\
\hline 3 & $\begin{array}{l}\text { Kepraktisan } \\
\text { LKPD }\end{array}$ & 87,5 & Praktis \\
\hline 4 & $\begin{array}{l}\text { Waktu } \\
\text { penggunaan }\end{array}$ & 87,5 & Praktis \\
\hline
\end{tabular}

Untuk mengetahui apakah LKPD mudah dipahami siswa atau diberikan angket. Untuk mengetahui aspek penyajian, penggunaan, ketrbacaan dan waktu. Data hasil analisis angket untuk tiap indikator disajikan seperti Tabel 2.

Tabel 2. Hasil analisis angket praktikalitas respons siswa

\begin{tabular}{llll}
\hline No & Indikator & Rata-rata & Kriteria \\
\hline 1 & Daya tarik & 80,4 & Praktis \\
\hline 2 & Pengunaan LKPD & 80,1 & Praktis \\
\hline 3 & Kepraktisan LKPD & 82,2 & Praktis \\
\hline 4 & Waktu penggunaan & 79,3 & Praktis \\
\hline
\end{tabular}

Dari data wawancara dapat disimpulkan bahwa secara keseluruhan LKPD praktis dan mudah digunakan. Dari indikator kejelasan penyajian materi semua siswa menyatakan bahwa semua materi disajikan jelas dan mudah dipahami. Peserta didik berpendapat bahasa yang digunakan pada LKPD mudah dipahami. Peserta didik menyatakan tidak ada bahasa yang susah dipahami. Peserta didik senang sekali belajar dengan LKPD. Menurut peserta didik menggunakan LKPD membantu mereka dalam memahami materi dengan mudah. Peserta didik juga menyatakan senang dengan LKPD yang diberikan, karena ada gambar, cerita, dan tulisan yang menarik.

Perangkat pembelajaaran matematika yang baik hendaklah bersifat praktis. Kriteria yang dipakai untuk menilai praktikalitas dalam pengembangan perangkat pembelajaran ini adalah keterlaksanaan pembelajaran menggunakan perangkat pembelajaran matematika berbasis pendekatan metakognisi, kemudahan dalam penggunaan, kecukupan waktu yang disediakan dalam melaksanakan perangkat pembelajaran tersebut. Dalam menilai kepraktisan pada perangkat pembelajaran ini, maka dikumpulkan data melalui observasi pelaksanaan pembelajaran, angket praktikalitas yang diisi oleh peserta didik dan guru. Pelaksanaan pembelajaran dengan menggunakan perangkat pembelajaran matematika berbasis pendekatan metakognisi menunjukkan bahwa proses pembelajaran yang mampu mengasah kemampuan berpikir tingkat tinggi peserta didik.

Berdasarkan hasil angket dari guru diketahui juga pembelajaran dengan LKPD berbasis metakognisi sangat praktis. Hal ini juga didukung dari hasil wawancara yang dilakukan dengan guru. Menurut guru LKPD mudah digunakan baik dari segi petunjuk LPPD maupun dari isi LKPD. Langkah-langkah kegiatan pada LKPD mudah dimengerti. Hal ini juga didukung oleh kejelasan penyajian modul. Selain itu, menurut guru bahasa yang digunakan sebagian besar jelas. Hanya ada perlu sedikit perbaikan berdasarkan saran yang telah diberikan. Guru juga menyatakan bahwa tidak ada kendala yang berarti dalam belajar dengan LKPD.

Begitu juga dari wawancara dengan peserta didik menunjukkan bahwa LKPD yang 
digunakan sudah jelas, sangat menarik dan dapat membantu peserta didik memahami pelajaran dengan baik. Pernyataan ini sejalan dengan hasil kepraktisan LKPD berbasis pendekatan metakognisi menurut peserta didik dengan ratarata keseluruhan adalah $80,5 \%$ dengan kategori praktis. Secara umum waktu yang disediakan sudah cukup selama pelaksanaan pembelajaran dengan menggunakan perangkat pembelajaran berbasis pendekatan metakognisi.

Efektivitas perangkat pembelajaran dilihat dari kemampuan berpikir tingkat tinggi peserta didik setelah pembelajaran dengan menggunakan perangkat pembelajaran berbasis pendekatan metakognisi. Pada Tabel 3 dapat dilihat hasil analisis kemampuan peserta didik dengan indikator HOTS.

Tabel 3 Hasil analisis HOTS peserta didik

\begin{tabular}{|c|c|c|c|c|}
\hline No & $\begin{array}{l}\text { Indikator } \\
\text { HOTS }\end{array}$ & $\begin{array}{l}\text { No } \\
\text { Soal }\end{array}$ & $\begin{array}{l}\text { Pre- } \\
\text { test }\end{array}$ & $\begin{array}{l}\text { Post- } \\
\text { test }\end{array}$ \\
\hline \multirow[t]{4}{*}{1} & Analize & & & \\
\hline & Differentiating & 1,2 & 100 & 100 \\
\hline & Organizing & 7,1 & 32 & 96 \\
\hline & Attributing & $2,4 \mathrm{~b}$ & 69 & 91 \\
\hline \multirow[t]{3}{*}{2} & Evaluate & & & \\
\hline & Checking & 6 & 59 & 96 \\
\hline & Critiquing & 7,1 & 12 & 88 \\
\hline \multirow[t]{4}{*}{3} & Create & & & \\
\hline & Planning & $8,4 a$ & 43 & 65 \\
\hline & Generating & 5,7 & 33 & $95 \%$ \\
\hline & Producing & 3,5 & 22 & 59 \\
\hline
\end{tabular}

Efektivitas dalam penelitian dilakukan bertujuan untuk melihat seberapa jauh kegunaan dan manfaat dari LKPD berbasis pendekatan metakognisi untuk meningkatkan kemampuan berpikir tingkat tinggi peserta didik. Pada LKPD, peserta didik dilatih memahami masalah untuk kemudian merencanakan solusi sehingga peserta didik dilatih dalam pemecahan masalah (Lewy, Zulkardi, Aisyah, 2009). Pada kegiatan ini peserta didik diransang dengan pertanyaan metakognisi pada tahapan perencanaan.

Pertanyaan yang diajukan dapat berupa "Imformasi apa yang kamu dapat tabel diatas?", "Strategi apa yang kamu gunakan untuk meyelesaikan permasalahan diatas?" Pengajuan pertanyaan ini memberikan stimulus kepada peserta didik untuk memahami permasalahan yang diajukan kepada mereka serta menstimulus peserta didik menyusun perencanaan penyelesaiannya. Hal ini terlihat ketika diajukan pertanyaan ini peserta didik membaca kembali permasalahan untuk memahami dan menyusun rencana penyelesaiannya dengan konsep-konsep yang telah mereka pahami. Hal ini berarti peserta didik telah memiliki kemampuan penyusunan rencana dan pemecahan masalah. Salah satu indikator HOTS menurut Heong (Heong et al., 2011) adalah pemecahan masalah. Dengan demikian berarti peserta didik telah memenuhi salah satu indikator HOTS yaitu pemecahan masalah.

Peserta didik juga dilatih memonitor atau mengoreksi kembali pekerjaan yang mereka kerjakan dengan pertaanyaan metakognisi tahap monitoring. Pada kegiatan ini peserta didik diransang dengan pertanyaan metakognisi pada tahapan monitoring. Pertanyaan yang diajukan dapat berupa "Apakah kamu yakin yang kamu kerjakan benar?", 'Setelah menjawab pertanyan diatas, informasi apa yang perlu kamu ingat?". Pengajuan pertanyaan ini memberikan stimulus kepada peserta didik untuk mengoreksi kembali apa yang mereka kerjakan dan memantau pemahaman peserta didik. Hal ini terlihat ketika diajukan pertanyaan ini peserta didik mengoreksi kembali apa yang mereka kerjakan dan membaca kembali materi untuk mengoreksi pemahaman mereka.

Hal ini berarti peserta didik telah memiliki kemampuan mengoreksi (mengecek). Salah satu indikator HOTS menurut Karthwohl adalah checking dan critiquing yaitu kemampuan peserta didik untuk melacak ketidakkonsistenan suatu proses dan ketidakkonsistenan antara hasil dan kriteria yang mana kemampuan ini juga dapat dikatakan kemampuan berpikir kritis pada indikator HOTS (Lateef, Dahar, \& Latif, 2016). Dengan demikian berarti peserta didik telah memenuhi salah satu indikator HOTS yaitu checking dan critiquing atau kemampuan berpikir kritis.

Pada LKPD peserta didik juga diberikan stimulus dengan pertanyaan metakognisi tahap evaluation untuk dapat menggunakan berbagai ide dan gagasan serta mengkoneksikannya antara satu sama lain sehingga menghasilkan ide yang kreatif. Pertanyaan yang diajukan dapat berupa "Dapatkah kaamu menerapkan cara berpikir penyelesaian permasalahan ini untuk masalah 


\section{JURNAL GANTANG. Oktober 2019; IV(2): 143 - 153 \\ p-ISSN. 2503-0671 \\ e-ISSN. 2548-5547}

lainnya?", "'Dibagaian mana pada materi ini yang belum kamu pahami?", "Dapatkah kamu menyelesaikan dengan cara yang berbeda?”. Pengajuan pertanyaan ini memberikan stimulus kepada peserta didik untuk mengevaluasi secara keseluruhan pemahaman peserta didik terhadap materi yang dipelajari.

Hal ini terlihat ketika diajukan pertanyaan ini peserta didik menuliskan pada LKPD bagian mana pada LKPD yang mereka tidak pahamai dan kemudian bertanya pada guru, serta berusaha menemukan cara yang berbeda dalam menyelesiakan permalahan yang mereka kerjakan. Hal ini berarti peserta didik telah memiliki kemampuan mengevaluasi serta berpikir kreatif. Ada dua indikator HOTS menurut Karthwohl yang dapat dicapai dalam hal ini yaitu adalah evaluation dan create. Dengan demikian berarti peserta didik telah memenuhi dua indikator HOTS yaitu evaluation dan create.

Pada LKPD tidak hanya kegiatan pembelajaran dengan pendekatan metakognisi dalam rangka melatih HOTS peserta didik yang diajukan secara beulang-ulang namun pada LKPD juga disajikan soal-soal pada level HOTS. dalam penyelesaian soal-soal latihan peserta didik dituntun dengan pertanyaan-pertanyaan metakognisi. Sebagaimana yang dinyatakan Limbach (Kurniati, Harimukti, \& Jamil, 2016) ada lima langkah pembelajaran yang dapat ditempuh dalam pengembangan HOTS, yakni: (1) menentukan tujuan pembelajaran, (2) mengajarkan melalui pertanyaan, mempraktikan, (4) menelaah, mempertajam dan meningkatkan pemahaman, dan mempraktikan umpan balik dan menilai pembelajaran. Dengan demikian dapat dikatakan perangkat pembelajaran berbasis pendekatan metakognisi memberikan efek terhadap HOTS peserta didik (Ganaphaty, 2017).

Selanjut pengujian keefektifitasan berdasarkan penilaian HOTS peserta didik yang diperoleh melalui tes dengan soal-soal pada level HOTS. Tes dilakukan sebanyak dua kali yakni tes awal dan tes akhir. Tes awal dilakukan sebelum melakukan pembelajaran dengan perangkat pembelajaran berbasis pendekatan metakognisi serta tes akhir setelah melakukan pembelajaran dengan perangkat pembelajaran berbasis pendekatan metakognisi. Berdasarkan hasil analisis dari tes awal rata-rata nilai yang diperoleh peserta didik adalah 51,41 dengan persentasi dari $50,4 \%$ peserta didik yang nilainya diatas KKM. Hasil analisis dari tes akhir ratarata nilai yang diperoleh adalah 77,41 dengan persentase $77,9 \%$ peserta didik yang nilainya diatas KKM. Dengan demikian berdasarkan kriteria keefektifitasan berdasarkan hasil belajar menunjukkan bahwa hasil belajar matematika peserta mengalami peningkatan. Dengan demikian berdasrkan kriteria efektivitas yaitu memberikan efek dan meningkatkan hasil belajar maka perangkaat pembelajaran berbasis pendekatan metakognisi efektif dalam meningkatkan HOTS peserta didik.

\section{Kesimpulan}

Hasil penelitian menunjukan LKPD berbasis pendekatan metakognisi untuk HOTS yang dikembangkan sudah valid baik dari segi isi maupun konstruk. Selanjutnya, LKPD praktis dari segi petunjuk penggunaan, bahasa dan tahapan metakognisi, kemudahan penggunaan, dan waktu yang dibutuhkan, serta efektif untuk meningkatkan HOTS peserta didik dari hasil pretest dan postest.

\section{Referensi}

Abdullah, A. A., \& Richardo, R. (2017). Menumbuhkan kemampuan berpikir kritis siswa dalam memilih makanan sehat dengan pembelajaran literasi matematika berbasis konteks. Jurnal Gantang, 2(2), 89-97. https://doi.org/10.31629/jg.v2i2.193

Akker, J. J. H. van den (Jan J. H., Plomp, T. (Tjeerd), Bannan, B., Cobb, P., Folmer, E., Gravemeijer, K. (Koeno P. E., ... SLO (2000- ). (2013). Educational design research / Part A: an introduction.

Ali, A. \&, \& Zulkifli, Z. (2016). The development of students' capabilities in Higher Order Thinking Skill (HOTS) through science education. Jurnal Pemikir Pendidikan, 7, 73-88. https://doi.org/http://dx.doi.org/10.1093/ne uonc/nox036

Astuti, P., Purwoko, P., \& Indaryanti, I. (2017). Pengembangan LKS untuk melatih kemampuan berpikir kritis dalam mata pelajaran matematika di kelas VII SMP. 
Jurnal Gantang, 2(2), 145-155. https://doi.org/10.31629/jg.v2i2.244

Heong, Y. M., Othman, W. B., Yunos, J. B. M., Kiong, T. T., Hassan, R. Bin, \& Mohamad, M. M. B. (2011). The level of marzano higher order thinking skills among technical education students. International Journal of Social Science and Humanity, 1(2), 121-125. https://doi.org/10.7763/ijssh.2011.v1.20

Kamarudin, M. Y., Yusoff, N. M. R. N., Yamat, H., \& Abdul Ghani, K. (2016). Inculcation of Higher Order Thinking Skills (HOTS) in arabic language teaching at malaysian primary schools. Creative Education, 07(02), 307-314. https://doi.org/10.4236/ce.2016.72030

Kurniati, D., Harimukti, R., \& Jamil, N. A. (2016). Kemampuan berpikir tingkat tinggi siswa smp di kabupaten jember dalam menyelesaikan soal berstandar pisa. Jurnal Penelitian Dan Evaluasi Pendidikan, 20(2), 142. https://doi.org/10.21831/pep.v20i2.8058

Lai, E. R. (2011). Metacognition: A Literature Review Research Report. Research Reports, (April), 41. https://doi.org/10.2307/3069464

Lateef, A., Dahar, M. A., \& Latif, K. (2016). Impact of higher order thinking skills of university students on their academic performance. Science International (Lahore) Journal, 28(2), 2031-2035.

Lestari, C. F., Kristiana, A. I., \& Kurniati, D. (2016). Pengembangan paket tes matematika berbasis kemampuan berpikir tingkat tinggi siswa kelas X TKJ SMK materi sistem persamaan linier. Jurnal Edukasi, 3(2), 34. https://doi.org/10.19184/jukasi.v3i2.3527

Nasution, M. L., Yerizon, Y., \& Gusmiyanti, R. (2018). Students' mathematical problemsolving abilities through the application of learning models problem based learning. IOP Conference Series: Materials Science and Engineering, 335(1). https://doi.org/10.1088/1757899X/335/1/012117

Papleontiou-Louca, E. (2003). The concept and instruction of metacognition. Teacher Development, 7(1), 9-30. https://doi.org/10.1080/1366453030020018 4

Prasetyani, E., Hartono, Y., \& Susanti, E. (2016).
Kemampuan Berpikir tingkat tinggi siswa kelas Xi dalam pembelajaran trigonometri berbasis masalah di SMA Negeri 18 Palembang. Jurnal Gantang, 1(1), 34-44. https://doi.org/10.31629/jg.v1i1.4

Rooney, C. (2009). How am I using inquirybased learning to improve my practice and to encourage higher order thinking among my students of mathematics? Educational Journal of Living Theories, 5(2), 99-127.

Services, L. (2009). Metacognition. 2-4.

Thompson, T. (2008). Mathematics teachers interpretation of higher-order thinking in Bloom's Taxonomy. International Electronic Journal of Mathematics Education, 03(02).

Widodo, T., \& Kadarwati, S. (2013). To Improve learning achievement. Cakrawala Pendidikan, 32(1), 161-171.

Yerizon, Y., Putra, A. A., \& Subhan, M. (2018). Student responses toward student worksheets based on discovery learning for students with intrapersonal and interpersonal intelligence. IOP Conference Series: Materials Science and Engineering. https://doi.org/10.1088/1757899X/335/1/012113 
JURNAL GANTANG. Oktober 2019; IV(2): 143 - 153

p-ISSN. 2503-0671

e-ISSN. 2548-5547 